\title{
A HUMAN RIGHTS AND ETHICAL LENS ON SECURITY AND HUMAN DIGNITY: THE CASE STUDY OF SYRIAN ASYLUM SEEKERS
}

\section{Francesca VIETTI and Roberto FRANZINI TIBALDEO}

\begin{abstract}
The article tackles the plural and evolving concepts of security by analysing their relation to human rights and ethics. Although the general impression is that seldom the security discourse is associated with the respect of human rights and ethics, at least from a theoretical point of view security is indeed intertwined with those normative features (first thesis). Moreover, ethics and human rights can be valuably and usefully employed to clarify issues related to security and eventually to suggest improvements in the political management of security issues (second thesis). We argue our theses by focusing on a case study of particular relevance to the present day debate on security: the Syrian asylum seekers headed to Europe. In our ethical and human rights enquiry into this case study we consider multiple aspects related to security ('de jure' or normative, 'de facto' and perceptive-societal) and the interpretative lens provided by ethics and human rights sheds light on the crucial and manifold centrality played by the notion of human dignity.
\end{abstract}

Keywords: Ethics, human rights, fundamental rights, human security, asylum, Europe, European Union, human dignity, Syrian asylum seekers, human mobility, smuggling.

\section{Introduction}

The term security has turned to be omnipresent in our daily lives, both in the public and in the private sphere. If in its classical sense, security, from the Latin securitas, referred to composure, tranquillity of spirit, freedom from care, the condition that Cicero named "the absence of anxiety upon which the happy life depends," nowadays it is defined by the Oxford English Dictionary as "the state of being free from danger or threat." The current concept of security is far from being monolithic or static. It is rather plural, contextual, differently perceived according to historical background as well as different internal and external threats and challenges identified in a given territory by the institutional stakeholders.

In the contemporary reflection on the plural concepts of security, it is of key importance to analyse their relation to human rights and ethics: are the aims of security 
conflicting with the ones set forth by human rights and ethics? Do they exclude each other? Or should they be consistent and converge? Of course, the general impression is that seldom is the security discourse associated with the respect of human rights and ethics, although - as we shall see-it should be, at least from a theoretical point of view. We shall try to clarify some of the reasons behind this apparent lack of cooperation. On the other hand, we wish to demonstrate that, despite this situation, ethics and human rights can be valuably and usefully employed to clarify issues related to security and eventually to suggest improvements in the political management of security issues.

The first section of the article will focus on the way security has been reframed, in the light of human rights, from the Westphalian model to the paradigm of human security. The second section will investigate the relation among ethics, human rights and security. It will introduce the instrumental concept of 'ethical and human rights lens' and will focus on the implications that an in-depth look can have into issues labelled as 'security or emergency situations.' The challenges and opportunities related to such approach will be explored in section three: in particular, we shall focus on the case study of the Syrian asylum seekers headed to Europe. The article will close with some reflections, proposals and recommendations as regards conceivable ways of overcoming theoretical and practical divergences among security, ethics and human rights.

\section{The Current Reframing of Security}

\section{The Westphalian Paradigm and Its Crisis}

The $17^{\text {th }}$ century Westphalian realistic paradigm of security, which was at the base of the modern State system and predominant in international relations in the last centuries, was exclusive, militaristic, boundary, territorial and State-centred; namely, it acknowledged States as the only relevant political subjects. Indeed, their perspective on security was far from being complex: as remarked by Hans J. Morgenthau "all history shows that nations active in international politics, like other politics are continuously preparing for, actively involved in, or recovering from organized violence in the form of war" ${ }^{2}$ consistently with the motto 'si vis pacem para bellum,' namely, if you want peace, prepare for war.

In the 1980s the Copenhagen School of security studies criticised the traditional paradigm of security for the following reasons: a) the State-centeredness of the latter is not able to provide insight into new menaces to security originating from different kinds of actors, such as terrorists for instance; thus new levels of analysis are required (namely, the individual and the international one in addition to the State level of analysis); b) the traditional primacy of militaristic security is too narrow; a more 
holistic perspective on security is required, one which aims at taking into account also other sectors relevant to security like the economic, political, environmental and societal, in addition to the militaristic and territorial ones; ${ }^{3}$ c) the traditional, objective and realistic approach to security falls short of understanding its societal relevance; indeed, menaces to security are often characterised by a process of social and perceptive construction, called "securitisation." Securitisation is a form of extreme politicisation, when securitising actors (such as politicians, bureaucracies, governments, lobbies etc.) perceive and narrate that a menace is so urgent and foremost that it even legitimates breaking the rules in order to gain security. ${ }^{4}$

Securitisation has proved to be a useful concept in order to enquire into how to commence and fulfil a process of de-securitisation. However, as evidenced by several episodes of these last years, and especially by $9 / 11$, it exhibits a certain weakness as regards its explanatory and predictive capacity. ${ }^{5}$ Moreover, regarding its approach to security, the Copenhagen School has been criticised for its unwillingness to admit that the dynamics of securitisation/de-securitisation has to be tackled first politically and not analytically. ${ }^{6}$ The reason behind this criticism lies in the fact that, even when in present day democracies politics proves to be negligent as regards its duties, it still is a fundamental actor of the security discourse, one - as we shall see-endowed with 'normative' responsibility. This means that the dynamics of securitisation/de-securitisation raises questions about the type of politics we want, whether that is democratic politics of universal norms (like, for instance, those related to human rights) and slow procedures or the exceptional politics of speed and enemy exclusion.

\section{Human Rights Sowing the Seeds of Human Security}

The establishment of the Organization of the United Nations in 1945, in the aftermath of the World War II, instilled a profound change in the way security and international relations had been perceived until that moment. Far from the exclusive, militaristic State-centred realistic paradigm, the United Nations established a system of collective security to prevent and remove threats to peace, suppress acts of aggression and settle international disputes by endowing the Security Council with the primary responsibility for the maintenance of international peace and security. The Charter of the United Nations ${ }^{7}$ laid the foundation for a broader, comprehensive concept of security by acknowledging the need to promote the universal respect for and observance of human rights and fundamental freedoms and with a view to the creation of stability and well-being which, as stated in article 55, are necessary for peaceful and friendly relations among nations. Three years later, the Universal Declaration of Human Rights ${ }^{8}$ acknowledged for the first time that all human beings are born free and equal in dignity and rights, without distinction of any kind, and it further recognised that "everyone is entitled to a social and international order in which the rights and freedoms set forth in this Declaration can be fully realized" 
(article 28). This had profound implications on the way international relations and security were framed, as they needed to be conducive to the full realisation of human rights.

The codification of human rights treaties at an international and regional level in the last seventy years contributed to further specifying the contents of such rights on the one hand, and to strengthening their protection by establishing monitoring and supervisory mechanisms, on the other. In such a fruitful framework, several soft law documents ${ }^{9}$ and reports by Independent Commissions ${ }^{10}$ investigated the relation among security, development and disarmament, the interdependence between States' and citizens' security, the need to encompass matters beyond military threats to build peace, stability and security, ${ }^{11}$ sowing the seeds of a new concept of security, which put human beings at the centre.

From the early 1990's onwards, the concept of human security gained absolute relevance in the international debate. The 1994 UNDP Report acknowledged that "for too long nations have sought arms to protect their security" and defined human security as being composed of two main dimensions: freedom from want and freedom from fear. ${ }^{12}$ The Report marked a trend reversal as it called for urgent change of the concept of security along two ways: from the exclusive focus on territorial security to a much greater stress on people's security and from security through armaments to security through sustainable human development. ${ }^{13}$

A few years later, the Commission on Human Security clarified that human security entails "protecting fundamental freedoms that are the essence of life, $[\ldots]$ protecting people from critical (severe) and pervasive (widespread) threats and situations, [...] using processes that build on people's strength and aspirations." ${ }^{\text {"14 }}$ It further provided some reflections on the dynamic nature of the concept of human security since what people consider being vital and the essence of life varies across individuals and societies. Operationally, to adopt a human security approach in the design, implementation and assessment of policies according to such paradigm implies responsive and sustainable measures that need to be consistent with the following principles of human security: people-centred, multi-sectoral, comprehensive, context-specific and prevention-oriented. ${ }^{15}$

\section{Human Rights and Security Strategies in Europe}

At the regional level, Europe relies on two main human rights treaties: the European Convention for the protection of human rights and fundamental freedoms (ECHR) ${ }^{16}$ adopted in 1950 in the framework of the Council of Europe and the Charter of Fundamental Rights of the European Union (CFREU). ${ }^{17}$ The Charter, inspired by the constitutional traditions and international obligations common to Member States, the ECHR, the European Social Charter as well as the case law of the Court of Justice 
and of the European Court of Human Rights, further expanded the contents of the ECHR. Both human rights instruments acknowledge "the right of everyone to liberty and security of person" ${ }^{\prime 18}$ which protects against any arbitrary interference by the State. It should be underlined that States do not enjoy unlimited discretion to counteract threats to their national security such as terrorism, since they are bound to human rights and the rule of law. ${ }^{19}$ In exceptional circumstances such as in times of war or other public emergency threatening the life of the nation, States may unilaterally derogate from some of their obligations to ECHR "to the extent strictly required by the exigencies of the situation, provided that such measures are not inconsistent with its other obligations under international law. ${ }^{20}$ Limitations must be subjected to the principle of proportionality, may be introduced only if they are necessary, required by the exigencies of the situation and genuinely meet the objectives of general interest or the need to protect the rights and freedoms of others. In particular, fundamental human rights can never be derogated from, namely the right to life, the prohibition of torture, the prohibition of slavery or servitude, no punishment without law, abolition of death penalty, the right not to be tried or punished twice. ${ }^{21}$

In the past years the European Union has adopted some security strategies to orient its action in the domain of internal and external security, which make reference to the importance of promoting and protecting human rights. A Secure Europe in a Better World, ${ }^{22}$ adopted by the European Council in 2003, identified terrorism, proliferation of weapons of mass destruction, regional conflicts, State failure and organised crime as the main threats to security. It further acknowledged that "security is a precondition to development" and that "in much of the developing world, poverty and disease cause untold suffering and give rise to pressing security concerns." ${ }^{, 23}$ In particular, it recognised that the best means of strengthening international order entail "spreading good governance, supporting social and political reform, dealing with corruption and abuse of power, establishing the rule of law and protecting human rights." ${ }^{24}$ The Report on the Implementation of the European Security Strategy (ESS) Providing Security in a Changing World, adopted in 2008, further underlined "the need to continue mainstreaming human rights issues in all activities in this field, including ESDP missions, through a people-based approach coherent with the concept of human security." 25 It further highlighted the "shared responsibility to protect populations from genocide, war crimes, ethnic cleansing and crimes against humanity."26

As to the internal domain, the EU Internal Security Strategy Towards a European Security Model, ${ }^{27}$ adopted by the European Council in 2010, explicitly acknowledged that "Europe must consolidate a security model, based on the principles and values of the Union: respect for human rights and fundamental freedoms, the rule of law, democracy, dialogue, tolerance, transparency and solidarity." ${ }^{28}$ In particular, "the concept of internal security must be understood as a wide and comprehensive concept 
which straddles multiple sectors in order to address these major threats and others which have a direct impact on the lives, safety and well-being of citizens, including natural and man-made disasters such as forest fires, earthquakes, floods and storms. ${ }^{29}$ The respect, protection and safeguard of the rights and freedoms of EU citizens, and those residing or staying in the EU, form a cornerstone of the ISS. ${ }^{30}$

Finally, the European Agenda on Security, adopted in April 2015, ${ }^{31}$ sets out a shared approach on how the Union could bring added value to support the Member States in ensuring security. The Agenda prioritises the following three main threats: terrorism, organised crime and cybercrime, and further specifies that "security and respect for fundamental rights are not conflicting aims, but consistent and complementary policy objectives." 32

\section{Human Rights, Ethics and Security ${ }^{33}$}

\section{The Pivotal Role Played by Ethical Reflection}

As already emphasised, the reframed meaning of security is intrinsically related to the effort of protecting and empowering human rights. ${ }^{34}$ Human rights provide a 'normative' framework, viz. an 'ought' perspective thanks to which it is possible to understand, interpret and eventually assess the 'is' level, namely specific events as well as overall trends related - in this regard - to the issue of security. Indeed, the understanding of the 'is' through the lens of the 'ought' provides useful insight for actions and measures to be taken in order to achieve security, especially in controversial and complex cases. Besides, consistently with the debate on liberty started in the $17^{\text {th }}$ century, ${ }^{35}$ achieving security requires to safeguard the basic conditions of individual and social existence (security-from) so that the human being is able to fully flourish and accomplish his or her existence according to satisfactory standards of humanity (security-to).

The branch of philosophy dealing with actions and their relationship to 'normative' issues and the 'ought' perspective is called ethics. Ethics highlights precisely a 'normative' feature, since it involves comparing the human conduct with its 'ought-tobeing' dimension. Traditionally, although the latter has been variously identified with regards to its foundation, content, characteristics, and aims, it has been generally identified with what is 'right,' 'good,' 'just,' in opposition to what is 'wrong,' 'evil,' 'vice.'

What is the point in ethics? To what extent is it of some use to the topics we are considering (security and human rights)? A first answer supplied by the Western philosophical tradition is the following: ethics provides a rational and theoretical understanding of the gap between 'is' and 'ought,' so that individuals can consequently address their conduct as to bridge such a gap. Accordingly, ethical reflection is a pro- 
cedure of logical-argumentative confrontation, and an attempt to justify the norms regulating public and social life. As a result, ethical reflection confers priority to the juridical dimension, and shows plain indifference towards (a) an inquiry into fundamental questions of sense, and (b) a thorough investigation into the unity, integrity and complexity of personal existence. ${ }^{36}$

This is, however, only a first (indeed, reductive and inadequate) answer to the aforementioned questions. A different response-one that is more stimulating for our topic - is the following: ethics ought to effectively interact with deeds by providing ethical principles viz. general guides of action, whose aim is to "provide a standard of relevance or "reasonableness" ${ }^{\text {"37 }}$ for human conduct (both at an individual and a social level).

As the result of its semantic reframing, ethics provides a heuristic tool (or a critical and reflective lens) ${ }^{38}$ enabling us to understand how we can sensibly fulfil a meaningful life and a proper 'human' existence. ${ }^{39}$ From this perspective, ethics—just like human rights - is based on human dignity, ${ }^{40}$ as a notion endowed with 'normative' relevance. This means that human dignity is something that ought to be pragmatically fostered in compliance with specific ethical concepts (such as universality, equality, individuality, human flourishing) and operational guidelines.

Thus, on the one hand, ethics and human rights share a commonality, since both are based on the core notion of 'human dignity.' On the other hand, however, it is precisely thanks to the philosophical and ethical reflection of the last centuries, which gave a thorough contribution to the shaping of the 'ought' dimension, that the very notion of 'human rights' was finally achieved and theorised. In particular, the philosophical reflection encouraged an understanding of the 'ought' dimension through the lens of the aforementioned concepts, which were practically operationalised into corresponding 'normative' claims and guidelines. ${ }^{41}$ The so-called 'human rights' are the result of this process: indeed, human rights are valid for all human beings (universalisation claim) and apply unconditionally (categorical claim). They are valid for all individuals to the same extent (equalitarian claim) and they hold good for each human being (individualisation claim). Finally, they aim at the thorough and concrete development of each human being's potential (human flourishing claim).

\section{The 'Ought' Perspective on Security}

Let us now return to security. As already stated, human rights are inherent to every human being by virtue of being human, and based on the dignity of every human being. And their recognition and codification in the recent past contributed to shaping the notion of security as human-centred and multidimensional. Moreover, the previous paragraph highlighted that human rights and ethics provide a 'normative' framework thanks to which it is possible to understand and assess specific events and over- 
all trends related to security. How can this be understood in detail? A preliminary remark: the present day interest for security is set within an overall framework characterised by vulnerability (of nature as a whole, of the human nature, of individuals, groups and societies, etc.), complexity, uncertainty, fear, need for governance, individual and social pathologies, challenges and risks related to technological development, globalisation and multiculturalism-interculturalism. ${ }^{42}$ Hence, the need for ethics related to security. Thanks to its claims and essential connection to human rights, ethical principles and the human rights paradigm aim at: (a) recognising and detecting potential menaces and threats to human rights in security issues; (b) understanding and assessing the relevance of these issues in a multilevel perspective ('de jure,' societal perception, 'de facto'); and (c) promoting individual and social awareness, responsibility, participation etc. in the resolution of issues related to security. ${ }^{43}$ Furthermore, in those cases where there is a conflict between moral or normative principles (for instance, the opposition between community security and personal freedom or the one between solidarity and economic security), ${ }^{44}$ ethics provides human-centred guidelines (namely, the human rights) for achieving reasonable accommodation and trade-offs between different goals, and eventually for going beyond those tradeoffs. ${ }^{45}$

\section{A Human Rights and Ethical Lens on Security}

The reflections of the previous paragraphs clarified the interconnection and interdependence between ethics, human rights and security. Operationally, the adoption of the human rights and ethics approach acts as a critical lens, which allows an in-depth look at certain issues, events or policies. Adopting such a lens implies re-considering security threats, strategies/policies and issues in terms of 'security of whom?,' 'security from what?,' 'security by what means?'. ${ }^{46}$

Such a lens helps to shed light on the probable distance between existing phenomena or threats to security (the 'de facto' dimension), the related societal perception and the principles enshrined in soft law documents as well as the rights acknowledged in legally binding treaties and conventions (namely, the 'de jure' dimension). Moreover, the lens provides guidelines for the policies to be adopted in order to operationally bridge the gap between 'de jure' and 'de facto.' It also allows to assess the ethical and human rights consistency and implications of such policies and measures.

\section{The Case of Syrian Asylum Seekers Headed to Europe}

A decade ago, the Global Commission on International Migrations recommended that "women, men and children should be able to realise their potential, meet their needs, exercise their human rights and fulfill their aspirations in their country of origin, and hence migrate out of choice, rather than necessity." ${ }^{, 47}$ Nevertheless, due to conflicts and persecution, in 2014 the number of displaced persons, refugees and 
asylum seekers worldwide has exceeded 50 million people for the first time following the World War II, mainly due to the war in Syria. ${ }^{48}$ Currently 59.5 million people are forcibly displaced worldwide, including 19.5 million refugees mostly living in developing countries. ${ }^{49}$

In this regard, the Syrian conflict has produced unprecedented displacement and refugee flows: Syria has turned both into the country with the highest number of internally displaced people (7.6 million $)^{50}$ and into the largest source country of refugees. Currently 4,088,078 Syrian refugees are registered in Syria's neighbouring countries, namely Lebanon, Jordan, Turkey, Iraq, Egypt and other northern African countries. ${ }^{51}$ A small percentage of Syrians have also headed to Europe; it is estimated that between April 2011 and July 2015, 348,540 Syrians have applied for international protection in 37 European countries (47 percent of them in Germany and Sweden). ${ }^{52}$ The European Charter of Fundamental Rights acknowledges the right to asylum (article $18) .^{53}$

A human rights and ethical lens allows to look more in-depth into the phenomenon of Syrians heading to Europe both by sea and by land, by considering this phenomenon in view of these three questions: Security from what?, Security of whom?, and Security by what means? The first question allows us to look more in-depth into the threats undermining Syrians' security in their daily lives, while the other two questions, which are closely interrelated, allow us to uncover whether the human security has been prioritised in recent years and which means were employed to achieve such security.

Syrians are heading to Europe in search of freedom from fear as their security is threatened by conflict, persecution and war. According to data from Frontex, in 2014 Syrian was the top nationality being detected for illegal border crossing in the European Union, both by land and sea. ${ }^{54}$ Recent data confirm that out of 485,500 people who entered Greece and Italy between 1 January and 18 September 2015, more than 182,000 were Syrians. ${ }^{55}$ In particular, Syrians are the top nationality being smuggled to Greece both by land and sea and the fifth nationality landing in Italy. ${ }^{56}$

A human rights and ethical lens allows to question the reason why people in need of and entitled to international protection resort to illegal border crossing, namely to smugglers, to reach Europe. It further sheds light on the implications of such phenomenon. ${ }^{57}$ Indeed, there are extremely limited legal channels available to Syrians in search of human security to reach Europe safely: pledges by the European Union Member States for resettlement and other forms of admission (such as humanitarian admission and humanitarian visas) ${ }^{58}$ for Syrian refugees are extremely modest if compared to the number of Syrians in need of resettlement, estimated 377,700 in $2015 .^{59}$ Furthermore, the number of pledges for Syrians by EU Member States is far 
from being balanced, with some countries, such as Germany, currently providing more than 60 percent of European places. ${ }^{60}$

Due to extremely limited legal ways to reach Europe safely, these people have little alternatives but resorting to smugglers and putting their lives further at risk to access and enjoy such a fundamental right, as shown by the high number of migrants and asylum seekers of different nationalities, who died in the Mediterranean, estimated 3,419 in 2014. ${ }^{61}$ From 1 January 2015 till 29 September 2015, 2,892 asylum seekers and migrants are reported to have died or be missing in the attempt to cross the Mediterranean Sea. ${ }^{62}$ Although no comprehensive data are available, recent events such as the bodies found inside a truck at the side of the main highway between Budapest and Vienna ${ }^{63}$ may lead us to think that smuggling of asylum seekers by land both to EU Member States, as well as to European countries which are entry points to the EU, is causing increasing death among migrants and asylum seekers. Recently, due both to the pressure of the International community and the social mobilisation of European citizens in favour of the refugees, among other things, some European Union Member States have opened their borders to asylum seekers mainly coming from Syria who themselves walked into Europe ${ }^{64}$ paying smugglers and putting their lives at risk. ${ }^{65}$ Other countries are, however, attempting to seal their borders through the erection of fences, leaving asylum seekers stuck in a limbo. ${ }^{66}$ Some reflections may be made in this regard: first of all, people in search of human security should not be left without other solutions but turning to smugglers in order to apply for asylum in those European Union countries which recently adopted an open door policy. For too long the human security of civilians fleeing the Syrian conflict, as well as asylum seekers from other countries, has been neglected and disregarded by both politics and public discourse. Having little alternatives but risking one's life to enjoy some form of protection is against human dignity - a principle which is enshrined at article 1 of the European Charter of Fundamental Rights and that has been recently recalled by the President of the European Commission. ${ }^{67}$ The right to asylum should entail the right to access the territory and the institutions responsible for receiving asylum application safely and consistently with the principle of human dignity. ${ }^{68}$ In this regard, what the European Union and its Member States still 'ought' to do is to willingly and effectively cooperate in order to make the right to asylum accessible and utilisable 'de facto.' In other words, the 'de jure' recognition of such an important right needs to be complemented by concrete policies, which make possible for people in need of international protection to access the European Union Member States safely. In this regard, far from implementing open door policies in some EU countries and erecting fences in others, a prompt and more significant increase in the number of legal ways to reach the EU would allow Syrian asylum seekers to achieve human security by means which are consistent with human dignity. 


\section{Concluding Remarks}

In this article we endeavoured to adopt a 'normative' framework, namely the human rights and ethical approach to security, which we tried to operationalise through three questions: Security from what?, Security of whom?, and Security by what means? We achieved results with regards to the following aspects of security: 'de jure' or normative (the priority of the relationship between human/fundamental rights in the European legislation and the special focus on human dignity), 'de facto' (the political and operational difficulty in agreeing and putting into practice adequate policies and measures in order to protect, safeguard and prevent the exploitation of human dignity), and perceptive-societal (the role played by public opinion in the political response to security issues).

In particular, the case study of Syrian asylum seekers headed to Europe shows that security and human rights are still far from being considered really "consistent and complementary policy objectives." ${ }^{\prime 9}$ What is worse, the human rights violations experienced by migrants and asylum seekers smuggled by sea and land to Europe, mainly in transit countries, were far from being unpreventable and unavoidable. Their death in the attempt to reach safety is the result of lack of alternatives and legal channels to reach Europe in a dignified and safe way. Human rights, on the contrary, are a matter of freedom and alternatives. And it is the specific duty of politics to foresee, if possible, and aim at beating the menaces to anyone's freedom of choice between alternatives.

The recent policy development agreed at the European Union level, with the decision, taken by large majority, to relocate 120,000 asylum seekers ${ }^{70}$ from EU frontline countries represents a meaningful step forward in terms of sharing responsibility among EU Member States, but at the same time shows that some EU countries such as Hungary, Romania, Slovakia and the Czech Republic are still divided on this issue. ${ }^{71}$ The great delay as well as the lack of unity in converging on such decisive issues evidences that the EU Member States still do not share, as they should, a common perspective on security and its connection to human rights and ethical issues. ${ }^{72}$ Most likely this division explains why at the present only in some countries asylum seekers are politically recognised and socially accepted as persons endowed with human rights, while elsewhere they are thoroughly perceived as a menace.

Progress should now be made on resettlement ${ }^{73}$ to avoid asylum seekers resorting to smugglers and thus risking their lives to access a fundamental human right. In a word, the European Union ought to establish a human rights-based, coherent and comprehensive migration policy, which makes human mobility its central asset. ${ }^{74}$ Moreover, policies regarding such essential matters should be discussed, agreed upon and adopted more promptly and straightforwardly by the European Union Member 
States in the future. If not, possible asylum seekers would be forced to continue recurring to smugglers and thus putting their lives at risk in order to reach Europe. We regret to confess that a lot of time has been wasted already and that from the point of view of those who are forced to abandon their homeland in search of human security, little has likely changed since the tragic events which took place off the coast of Lampedusa on 3 October 2013 when 366 migrants lost their lives. Our hope is that policies implemented in this field will start being human security oriented and that this will allow to broaden asylum seekers' and migrants' choices.

In addition to these results, we believe that the analysis of the Syrian asylum seekers case study through the human rights and ethical lens provides further insight. Firstly, it supplies a normative framework that puts human dignity at the core of any reflection focusing on security and thanks to which the safeguard of human dignity is the primary ethical duty, one that is stronger and more cogent than any other. This means that the ethical motivation to comply with human dignity should inspire: 1) law, 2) politics, and 3) individual and collective behaviour. The 2015 migrant and refugee crisis evidences a discrepancy among these three spheres: the EU fundamental legislation is in line with the safeguard of human dignity, while politics lacks in promptly providing effective and coherent migration policies. And what about the European citizens? In some States they showed enthusiasm and solidarity towards the asylum seekers, and this may be understood as a visible confirmation of the primacy of solidarity and human dignity. This highlights a second aspect connected to the employment of the human rights and ethical lens: the case of the Syrian asylum seekers evidences also from a practical point of view that it is not true that the safeguard of the human dignity of some and the economic security of others are essentially conflicting values. This is because core ethical values, like solidarity and the protection of human dignity, are somehow generative of social relationships and of the human flourishing of all those involved. ${ }^{75}$ As a result-and this is our third remark - the theoretical and practical relevance of human dignity along with its holistic connection to other aspects of security supplies guidelines for prioritising interventions and policies aiming at safeguarding human dignity and security.

In particular, as an overall framework, it helps understanding present day issues and challenges with a constant eye on what 'ought to be.' We wish to provide a little example, the examination of which requires indeed further research. In this article we focused on the case of Syrian asylum seekers. But what if the people trying to enter Europe in millions were, as it will likely be in the next decades, ${ }^{76}$ economic migrants in search of freedom from want, which is one of the dimensions of human security? And here come the difficulties (and a couple of questions) related to security: (a) if these migrants aspired to enter Europe legally, most likely they would have to give up, since there are very little (and quantitatively insufficient) legal and safe ways to 
do so and due to the inadequacy of an European migration policy; (b) but if they tried to enter irregularly, they would encounter severe security threats (risk of life, risk to be caught by the police and returned, ${ }^{77}$ risk to be exploited by underground labour markets etc.); and (c) would they have the support of the public opinion, as the Syrian asylum seekers? Would the politicians face the issue promptly and effectively? How to achieve a reasonable accommodation and trade-off (as suggested by the human rights and ethical perspective on security) between the diverging goals of the economic security of Europeans on the one hand and the safeguard of the migrants' human security (the fulfilment of which entails the right to be free from want) on the other hand?

Despite the complexity of this issue, we do believe that the human rights and ethical lens on security provides at least two useful indications: a) the human dignity of all human beings, and especially of those exposed to major threats or most vulnerable to human rights violations, 'ought' to be safeguarded; b) since the future of Europe and of the globalised world will be characterised by an increasing rate of cultural diversity, everyone-European citizens and foreigners alike - 'ought' to build strong and dynamic relationships with the so-called 'other,' to communicate effectively and to take care of him or her in order to make a contribution to building inclusive communities. $^{78}$

\section{Acknowledgement}

The research leading to these results has received funding from the European Community's Seventh Framework Programme (FP7/2007-2013) under Grant Agreement $\mathrm{n}^{\circ} 605142$. The authors thank the EvoCS project partners contributing to the discussions on the described work. Only the authors' views are reflected, the Commission and the Project are not liable for any use that may be made of the information contained therein.

\section{Notes}

1 Emma Rotschild, "What is security?," Daedalus 124, no. 3 (Summer 1995): 61.

2 Hans J. Morgenthau (revised by Thompson K.W.), Politics Among Nations: The Struggle for Power and Peace (New York: Alfred A Knopf, 1985).

3 Barry Buzan, People, States, and Fear (Brighton: Wheatsheaf, 1983).

4 Barry Buzan, Ole Wæver, Jaap de Wilde, Security. A New Framework of Analysis (Boulder: Lynne Rienner, 1998).

5 Carla Monteleone, "Sicurezza internazionale," in Pensare la complessità. Itinerari interdisciplinari, ed. S. Costantino and C. Rinaldi (Palermo: Sigma edizioni, 2004), 235-43.

6 Claudia Aradau, "Security and the democratic scene: desecuritization and emancipation," Journal of International Relations and Development 7, no. 4 (December 2004): 388-413, DOI: $10.1057 /$ palgrave.jird.1800030. 
7 United Nations, Charter of the United Nations (New York: UNTS XVI, 24 October 1945), available at http://www.un.org/en/charter-united-nations/.

8 UN General Assembly, Universal Declaration of Human Rights (217 A-III, 10 December 1948), available at http://www.un.org/en/documents/udhr/.

9 Declaration on the Strengthening of International Security, adopted on 16 December 1970 during the $1932^{\text {nd }}$ Plenary Meeting, available at www.un-documents.net/a25r2734.htm; United Nations Secretary General, An Agenda for Peace, Preventive Diplomacy, Peacemaking, Peace-keeping, 1992, A/47/277, available at www.unrol.org/doc.aspx?n=A_ 47_277.pdf; United Nations Secretary General, An Agenda for Development, A/48/935, 6 May 1994, available at http://www.un.org/ga/search/view_doc.asp?symbol=A/48/935.

${ }^{10}$ Independent Commission on Disarmament and Security Issues, 1982. Common responsibility in the 1990's: Stockholm Initiative on Global Security and Governance, April 22, 1991.

${ }^{11}$ United Nations Secretary General, An Agenda for Peace, Preventive Diplomacy, Peacemaking, Peace-keeping.

12 Freedom from fear and freedom from war, together with freedom speech and expression, second freedom of faith and religion were at the core of the "State of the Union Address," delivered by the United States President Franklin D. Roosevelt to the $77^{\text {th }}$ United States Congress on 6 January 1941.

${ }^{13}$ United Nations Development Program, Human Development Report 1994 (New York: Oxford University Press, 1994).

${ }^{14}$ Commission on Human Security, Human Security Now (New York, May 2003), available at www.humansecurity-chs.org/finalreport/index.html.

${ }^{15}$ United Nations Trust Fund for Human Security, Human Security in Theory and Practice: Application of the Human Security Concept and the United Nations Trust Fund for Human Security, 2009.

${ }^{16}$ Council of Europe, European Convention on Human Rights, 1950, available at http://www.echr.coe.int/documents/convention_eng.pdf.

${ }^{17}$ European Union, Charter of Fundamental Rights of the European Union, C/83/391, available at http://www.europarl.europa.eu/charter/pdf/text_en.pdf.

${ }^{18}$ Respectively article 5 ECHR and article 6 CFREU.

${ }^{19}$ Louise Doswald-Beck, Human Rights in Times of Conflict and Terrorism (Oxford/New York: Oxford University Press, 2011). Both the ECHR and the CFREU set forth the possibility for a State to take measures derogating from its obligations in times of war or another public emergency, to the extent strictly required by the exigencies of the situation, provided that such measures are not inconsistent under international law (Article 15 ECHR "Derogation in Time of Emergency"; article 52 CFREU "Scope and Interpretation of Rights and Principles").

${ }^{20}$ See European Convention on Human Rights, Article 15.

${ }^{21}$ Alan Greene, "Separating Normalcy from Emergency: the Jurisprudence of Article 15 of the European Convention on Human Rights," German Law Journal 12, no. 10 (2011): 1764-85. As to the relevant case-law, see for instance Akswoy v. Turkey, as well as A. and Others v. the United Kingdom.

${ }^{22}$ European Council, A Secure Europe in a Better World, European Security Strategy, 2003, available at https://www.consilium.europa.eu/uedocs/cmsUpload/78367.pdf.

${ }^{23}$ European Council, A Secure Europe in a Better World.

${ }^{24}$ European Council, A Secure Europe in a Better World. 
${ }^{25}$ European Council, Report on the Implementation of the European Security Strategy: Providing Security in a Changing World, 11 December 2008, available at http://www.consilium.europa.eu/uedocs/cms_data/docs/pressdata/en/reports/104630.pdf.

${ }^{26}$ European Council, Report on the Implementation of the European Security Strategy.

${ }^{27}$ European Council, Internal Security Strategy for the $E U, 2010$, available at http://www.cosilium.europa.eu/uedocs/cms_data/librairie/PDF/QC3010313ENC.pdf.

${ }^{28}$ European Council, Internal Security Strategy for the EU.

${ }^{29}$ European Council, Internal Security Strategy for the EU.

${ }^{30}$ European Commission, Communication from the Commission to the European Parliament and the Council, The Final Implementation Report of the EU Internal Security Strategy 2010-2014 (Brussels, 20.6.2014) COM(2014) 365 final.

${ }^{31}$ European Commission, Communication from the Council to the European Parliament, the Council, the European Economic and Social Committee and the Committee of the Regions, The European Agenda on Security $\operatorname{COM}(2015)$ 185, 28 April 2015, available at http://ec.europa.eu/dgs/home-affairs/e-library/documents/basic-documents/docs/eu_agenda_ on_security_en.pdf.

${ }^{32}$ European Commission, The European Agenda on Security.

${ }^{33}$ This section is a reworking of the contribution to the Analytical framework of the EvoCS project, http://evocs-project.eu/.

34 The primacy of human rights is what distinguishes this approach to security from traditional State-based approaches (see Study Group on Europe's Security Capabilities, A Human Security Doctrine for Europe: The Barcelona Report of the Study Group on Europe's Security Capabilities, Presented to EU Representative for Common and Security Policy, Javier Solana, 15 September 2014, available at http://eprints.lse.ac.uk/40209/1/A_human security_doctrine_for_Europe\%28author\%29.pdf; see also Human Security Study Group, A European Way of security: The Madrid Report of the Human Security Study Group comprising a proposal and background report, 8 November 2007, available at http://eprints.1se.ac.uk/40207/1/A_European_Way_of_Security\%28author\%29.pdf.

35 The idea of distinguishing between a negative (freedom-from) and a positive (freedom-to) sense of the term 'liberty/freedom' as one of the main contributions of modern philosophy is examined and defended by Isaiah Berlin in his 1958 lecture, reissued as Isaiah Berlin, "Two Concepts of Liberty," in Liberty, ed. Isaiah Berlin and Henry Hardy (London: Oxford University Press, 2002), 166-217, http://dx.doi.org/ 10.1093/019924989X.003.0004.

${ }^{36}$ Among the scholars arguing that such issues ought to be reappraised, see Paul Ricoeur, Oneself as another (Chicago: Chicago University Press, 1992).

${ }^{37}$ FP7, Concepts on Ethics, p. 6. Available at http://ec.europa.eu/research/participants/data/ref/ fp7/89878/ethics-concepts_en.pdf.

${ }^{38}$ See Donald A. Schön, The Reflective Practitioner. How Professionals Think in Action (New York: Basic Books, 1983); Matthew Lipman, Thinking in Education, Second edition (Cambridge: Cambridge University Press, 2003); Martha C. Nussbaum, Not for Profit. Why Democracy Needs the Humanities (Princeton: Princeton University Press, 2010).

${ }^{39}$ See Amartya Sen, Equality of what? Tanner Lectures on Human Values (Stanford: Stanford University, 1979); Hans Jonas, The Imperative of Responsibility (Chicago: University of Chicago Press, 1984); Amartya Sen, Commodities and Capabilities (North-Holland, 1985); Martha Nussbaum, Amartya Sen (eds.), The Quality of Life (Oxford: Oxford University Press, 1993); Amartya Sen, Development as Freedom (Oxford: Oxford University Press, 1999); Martha C. Nussbaum, Women and Human Development. The Capabilities Approach 
(Cambridge: Cambridge University Press, 2001); Martha Nussbaum, Creating Capabilities: The Human Development Approach (Harvard: Harvard University Press, 2011); Rosalind Hursthouse, "On Virtue ethics" (Oxford: Oxford University. Press, 2002); Anna Loretoni, Ampliare lo sguardo. Genere e teoria politica (Roma: Donzelli, 2014).

${ }^{40}$ After all, this result is not a surprise, since the Western philosophical reflection of the last 250 years culminates precisely in the achievement of the so-called 'human rights.' See Immanuel Kant's (1724-1804) statement according to which the humanity is an end in itself (Immanuel Kant, Fundamental Principles of the Metaphysic of Morals, 1785, accessed 5 May 2015, available at http://www.gutenberg.org/cache/epub/5682/pg5682.html). See also: Oviedo convention (1997, art. 1); Charter of Fundamental Rights of the European Union; Nussbaum, Women and Human Development.

${ }^{41}$ See, among others, John Rawls, A Theory of Justice (Cambridge: Belknap Press of Harvard University Press, 1971); Norberto Bobbio, The Age of Rights (Cambridge: Polity Press, 1996); Martha Nussbaum, Creating Capabilities; Agostinho dos Reis Monteiro, Ethics of Human Rights (Dordrecht: Springer, 2014); Anna Loretoni, Ampliare lo sguardo; Gereon Wolters, Globalizzazione del bene? (Salerno: Orthotes, 2015).

${ }^{42}$ See, for instance, Hans Jonas, The Imperative of Responsibility; Ulrich Beck, Risk Society: Towards a New Modernity (London: Sage, 1992); Will Kymlicka, Multicultural Odysseys: Navigating the New International Politics of Diversity (Oxford: Oxford University Press, 2007); Elena Pulcini, Care of the World: Fear, Responsibility, and Justice in the Global Age (Dordrecht: Springer, 2013); Anna Loretoni, Ampliare lo sguardo; Thomas Nail, The Figure of the Migrant (Stanford: Stanford University Press, 2015).

${ }^{43}$ See, for instance, European Commission, Internal Security, 2011, Special Eurobarometer 371, accessed 6 May 2015, available at http://ec.europa.eu/public_opinion/archives/ebs/ ebs_371_en.pdf.

${ }^{44}$ See, for instance, Thierry Balzacq and Sergio Carrera, eds., Security versus Freedom? A Challenge for Europe's Future (Farnham: Ashgate, 2006); Sharon Weinblum, "Beyond the Security vs. Liberty Paradigm: A New Look on Security Politics," in Democratic Citizenship and War, ed. Y. Peled, N. Lewin-Epstein, G. Mundlak, and J. Cohen (London: Routledge, 2010).

${ }^{45}$ European Group on Ethics in Science and New Technologies, Ethics of Security and Surveillance Technologies, 2014, $77 \mathrm{ff}$, available at http://bookshop.europa.eu/en/ethics-ofsecurity-and-surveillance-technologies-pbNJAJ14028/.

${ }^{46}$ Shahrbanou Tadjbakhsh and Anuradha Chenoy, Human Security: Concept and Implications (London: Routledge, 2007).

${ }^{47}$ Global Commission on International Migration, Migration in an Interconnected World: New Directions for Action, October 2005.

${ }^{48}$ UNHCR, "World Refugee Day: Global forced displacement tops 50 million for first time in post-World War II era," 2014, available at http://www.unhcr.org/53a155bc6.html.

${ }^{49}$ Data available at http://www.unhcr.org.uk/about-us/key-facts-and-figures.html.

${ }^{50}$ Data available at http://www.internal-displacement.org/global-figures.

${ }^{51}$ Data as updated on August 29, 2015, available at http://data.unhcr.org/syrianrefugees/ regional.php.

${ }^{52}$ Data refer to 37 European countries which provide monthly data to UNHCR, available at http://data.unhcr.org/syrianrefugees/asylum.php.

${ }^{53}$ Article 18 of the CFREU sets forth that "The right to asylum shall be guaranteed with due respect for the rules of the Geneva Convention of 28 July 1951 and the Protocol of 31 
January 1967 relating to the status of refugees and in accordance with the Treaty of the European Union and the Treaty on the Functioning of the European Union."

${ }^{54}$ Frontex FRAN Quarterly July September 2015: 49.

55 International Organization for Migration, "IOM: Latest Data on Europe Migrant Emergency," 18 September 2015, available at https://www.iom.int/news/iom-latest-dataeurope-migrant-emergency.

${ }^{56}$ IOM Missing Migrant Project, Mediterranean Update, 29 September 2015, available at http://missingmigrants.iom.int/sites/default/files/Mediterranean_Update_29_September.jpg.

${ }^{57}$ On the shipwreck of 11 October 2013 causing death of Syrian asylum seekers and Palestinian refugees, see Francesca Vietti, Migrants in Search of Human Security: Reflections on the Lampedusa Tragedies by an Italian Red Cross Field Officer, 23 October 2013, http://cmsny.org/migrants-in-search-of-human-security-reflections-on-the-lampedusatragedies-by-an-italian-red-cross-field-officer/.

${ }^{58}$ Resettlement refers to "the selection and transfer of refugees from a state in which they have sought protection to a third country that admits them - as refugees - with a permanent residence status." Humanitarian admission refers to the process by which countries admit groups from vulnerable refugee populations in third countries so as to provide temporary protection on humanitarian grounds. Source: www.resettlement.eu; Humanitarian visas fall into the domain of protected entry procedures which "from the platform of diplomatic representations, [allow] a non-national to approach the potential host state outside its territory with a claim for asylum or other form of international protection, and to be granted an entry permit in case of a positive response to that claim, be it preliminary or final." See Gregor Noll, Jessica Fagerlund and Fabrice Liebaut, Study on the Feasibility of Processing Asylum Claims outside the EU (the Danish Centre for Human Rights, European Commission 2002), available at http://ec.europa.eu/dgs/home-affairs/e-library/docs/pdf/asylumstudy_dchr_ 2002_en_en.pdf.

${ }^{59}$ UNHCR, "Resettlement and Other Forms of Admission for Syrian Refugees," available at http://www.unhcr.org/52b2febafc5.html. On July 20, 2015 the Justice and Home Affairs agreed on resettling through multilateral and national schemes 22,504 displaced persons in clear need of international protection. This is not limited to Syrian refugees but to refugees from all EU priority regions. With regard to resettlement and legal channels, the UN Special Rapporteur on the human rights of migrants suggested that wealthy countries should collectively offer to resettle one million Syrians over the next five years. See Gabrielle Jackson, "UN Expert: Rich Countries Must Take in 1 Million Refugees to Stop Boat Deaths," The Guardian, April 22, 2015, http://www.theguardian.com/world/2015/apr/22/unurges-wealthy-countries-to-take-one-million-syrian-refugees-in-next-five-years. With regard to the data regarding Syrians in need of resettlement, see UNHCR, Projected Global Resettlement Needs Report 2015, June 2014.

${ }^{60}$ ICMC, " $10 \%$ of Refugees from Syria: Europe's Resettlement and Other Admission Responses in a Global Perspective," 2015, available at: http://www.icmc.net/wp-content/ uploads/2015/07/10percentRefugees2bis.pdf.

${ }^{61}$ UNHCR, "UNHCR Urges Focus on Saving Lives as 2014 Boat People Numbers Near 350,000," 10 September 2014, available at http://www.unhcr.org/5486e6b56.html.

${ }^{62}$ IOM Missing Migrant Project, Mediterranean Update.

${ }^{63}$ On August 27, 201571 corpses were found inside a truck at the side of the main highway between Budapest and Vienna, available at https://www.amnesty.org/en/latest/news/ 2015/08/time-for-europe-to-end-the-refugee-shame/. 
${ }^{64}$ Laura Smith-Spark and Susannah Cullinane, "European Migrant Crisis: A Country-byCountry Glance," CNN, 6 September 2015, available at: http://edition.cnn.com/2015/09/06/ europe/migrant-crisis-country-by-country/. Moreover, the opening of the Member States borders has been characterised by some political ambivalence and hesitation, and has somehow evidenced the inadequacies of the Dublin Regulation, whose revision in 2016 will be possibly carried out by the European Commission (see European Commission, Communication from the Commission to the European Parliament, the Council, the European Economic and Social Committee and the Committee of the Regions, A European Agenda on Migration).

${ }^{65}$ Simona Sikmic, "From Syria to Serbia: The Migrants' Balkan Backdoor," Middle East Eye, 26 August 2015, available at: http://www.middleeasteye.net/news/syria-serbia-migrantsbalkan-backdoor-1184791364.

${ }^{66}$ Rick Lyman, "Bulgaria Puts Up a New Wall, but This One Keeps People Out," New York Times, 5 April 2015, available at www.nytimes.com/2015/04/06/world/europe/bulgariaputs-up-a-new-wall-but-this-one-keeps-people-out.html; Gauri van Gulik, "Time for Europe to End the Refugee Shame," Amnesty International, available at www.amnesty.org/en/ latest/news/2015/08/time-for-europe-to-end-the-refugee-shame/; Jamie Grierson and Matthew Weaver, "Croatia Moves Refugees to Hungarian Border - As It Happened," The Guardian, 19 September 2015, available at www.theguardian.com/world/live/2015/sep/18/ refugee-crisis-hungary-builds-border-fence-with-croatia-live-updates.

${ }^{67}$ European Commission, State of the Union 2015: Time for Honesty, Unity and Solidarity, 9 September 2015, available at http://europa.eu/rapid/press-release_SPEECH-155614_en.htm.

${ }^{68}$ Article 1 of the CFREU states that "Human dignity is inviolable. It must be respected and protected."

${ }^{69}$ European Commission, Communication from the Council to the European Parliament, the Council, the European Economic and Social Committee and the Committee of the Regions, The European Agenda on Security.

${ }^{70}$ Council of the European Union, Council Decision Establishing Provisional Measures in the Area of International Protection for the Benefit of Italy and Greece, 22 September 2015, $12098 / 2015$.

${ }^{71}$ Ian Traynor and Patrick Kingsley, "EU Governments Push Through Divisive Deal to Share 120,000 Refugees," The Guardian, 22 September 2015, available at www.theguardian.com/ world/2015/sep/22/eu-governments-divisive-quotas-deal-share-120000-refugees.

72 This is one of the results achieved by the EvoCS project among others. Moreover, the diversity of European and national security discourses is characterised by a further stratification: 'de jure,' 'de facto,' societal. See Milos Jovanovic et al., Non-traditional Transnational Security Challenges in Serbian, British and Dutch Security Discourses: A Cross-country Comparison, in Exploring the Security Landscape - Non-traditional Security Challenges, ed. Anthony Masys (Dordrecht: Springer, forthcoming).

${ }^{73}$ Council of the European Union, Justice and Home Affairs, 3405 ${ }^{\text {th }}$ Council Meeting, Brussels, 20 July 2015, http://www.consilium.europa.eu/en/meetings/jha/2015/07/20/.

${ }^{74}$ See the UN Special Rapporteur's June 2015 report on the EU, "Banking on Mobility over a Generation," available at http://www.ohchr.org/EN/HRBodies/HRC/RegularSessions/ Session29/Pages/ListReports.aspx.

${ }^{75}$ Martha Nussbaum, Women and Human Development: The Capabilities Approach (Cambridge: Cambridge University Press, 1999); John Kleinig, Nicholas G. Evans, "Human Flourishing, Human Dignity, and Human Rights," Law and Philosophy 32 (2013): 539-564; 
Mauro Magatti, Chiara Giaccardi, Generativi di tutto il mondo unitevi! Manifesto per la società dei liberi (Milano: Feltrinelli, 2014).

${ }^{76}$ See for instance Thomas Nail, The Figure of the Migrant.

${ }^{77}$ With regard to those who reach the European Union irregularly, the recent EU policy developments make clear that it is key to distinguish between asylum seekers, who are in need of protection, and economic migrants who, on the contrary, must be rapidly returned. Council of the European Union, Justice and Home Affairs. European Commission, Communication from the Commission to the European Parliament, the Council, the European Economic and Social Committee and the Committee of the Regions, A European Agenda on Migration, 13 May 2015, available at: http://ec.europa.eu/dgs/home-affairs/what-wedo/policies/european-agenda-migration/background-information/docs/communication_on_ the_european_agenda_on_migration_en.pdf.

${ }^{78}$ See for instance Ulrich Beck, "The Cosmopolitan Society and its Enemies," Theory, Culture and Society 19:1-2 (2002): 17-44.

Francesca VIETTI currently serves as Research Assistant at the Scuola Superiore Sant'Anna in Pisa where she investigates issues related to security, human rights, human mobility and forced migrations. In 2012 and 2013 she worked as Field Officer in Sicily and Lampedusa for the Italian Red Cross in the framework of the Praesidium Project. In her previous jobs, she acquired expertise on trafficking in human beings, human security, smuggling of migrants both in the Mediterranean and across Mexico's southern border, as well as on the social and health-related aspects of forced migrations. Among her publications are (with M. Bisi), "Caught in the Crossfire: The Impact of Foreign Fighters on IDPs, Refugees and Asylum Seekers from Syria and Iraq," in Foreign Fighters under International Law and Beyond, ed. A. de Guttry, F. Capone, and C. Paulussen (ASSER/Springer, forthcoming); (with T. Scribner), "Human Insecurity: Understanding International Migrations from a Human Security Perspective," Journal on Migration and Human Security 1, no. 1 (2013): 17-31; Migrants in search of Human Security: Reflection on the Lampedusa Tragedies by an Italian Red Cross Field Officer, published in the Center for Migration Studies (New York) at http://cmsny.org/2013/10/23/migrants-in-search-of-humansecurity-reflections-on-the-lampedusa-tragedies-by-an-italian-red-cross-field-officer/.

Roberto FRANZINI TIBALDEO is FNRS Chargé de recherche (Postdoctoral fellow) at the Université Catholique de Louvain, Belgium. His research focuses on contemporary nihilism and its relationship with technique, ethics, and utopia. Among his philosophical interests are intercultural studies, ethics and politics of responsibility, landscape ethics, philosophy for children/community, ethics and security. Among his recent publications are La rivoluzione ontologica di Hans Jonas. Uno studio sulla genesi e il significato di "Organismo e libertà" (Milano: Mimesis, 2009); "Hans Jonas' Gnosticism and Modern Nihilism, and Ludwig von Bertalanffy," Philosophy and Social Criticism 38, no. 3 (2012): 289-311; "Reframing and Practicing Community Inclusion. The Relevance of Lipman's P4C," Childhood and Philosophy 10, no. 20 (2014): 401-20; "La conoscibilità del mondo secondo Alexander von Humboldt e il peculiare ruolo svolto dall'esperienza del paesaggio," Rivista geografica italiana 122, no. 1 (2015): 1-14; (with P. Becchi), "The Vulnerability of Life in the Philosophy of Hans Jonas," in Human Dignity of the Vulnerable in the Age of Rights. Interdisciplinary Perspectives, ed. A. Masferrer and E. García (Dordrecht: Springer, forthcoming). 